\title{
APPENDIX \\ CREATIVE ETYMOLOGY: \\ “CAESAREAN SECTION" \\ FROM PLINY TO ROUSSET
}

Although the legend of Caesar's birth by Caesarean was well known in the Middle Ages, no text before the end of the sixteenth century used the term "Caesarean section." When was this term first used in a medical context? Was Julius Caesar really born by Caesarean? And if he was not, where does the term derive from? ${ }^{1}$ The association of Julius Caesar with Caesarean section was the result of a long and complicated process of etymological thinking. Medieval etymology was not a historical science; it did not work with phonetic laws, sound shifts, or reconstructive philology. Rather, it was a fundamental way of looking at the world, of making connections and of determining a given term's place in the scheme of things. The immense popularity of Isidore of Seville's Etymologies bears witness to the centrality of etymological thought in the Middle Ages.

In grammar and rhetoric, in history, geography, and exegesis, etymological methods were used. Going back to Plato's dialogue Cratylus and his ideas on the natural or conventional origins of language, the controversy over the ultimate source of words continued through the Middle Ages and formed an important part of medieval scholarship. Since the Greek word etymologia signified the search for truth (in or through words), ${ }^{2}$ it was believed that if only the true meaning of a word, especially of a proper name, were known one would have a grasp on the essence of this word, concept, or person. As E. R. Curtius has pointed out, Homer and Pindar indulged in etymological playing with names. ${ }^{3}$ In the New Testament, authorization for the interpretation of names can 
be found in Matt. 16:18, where Jesus calls Peter the rock on which the church will be built (Latin petra, "rock"). The etymological exploration of names as an exegetical technique became especially important in the works of Saint Jerome (for example, the Liber de nominibus hebraicis) as well as in those of Saint Augustine. Curtius quotes Augustine's play on the name of Paulus, supposedly named this way because he was the "minimus apostolorum," or the smallest of the apostles (Latin paulus, "small"; minimus, "the smallest"). 4

For many medieval scholars a close relationship existed between etymology and genealogy. Founding myths, for example, were often closely linked to proper names of historical or mythological figures. Thus Britain supposedly got its name from Brutus, one of Aeneas's descendants; the German town Jülich was said to derive its name from its founding father Julius Caesar. Examples of this kind could be multiplied endlessly. The etymological relationship between a name and its supposed source was such a common literary proceeding that it was expressed in certain formulas, such as nomen habet a (it gets the name from ...) or in Old French de ceo vint li nuns (the name comes from this . . .), a set expression found countless times in Wace's Roman de Brut (ca. II5O), which deals with the settlement of Britain by Trojan refugees. The faith in etymological explanations as a way to gain a more perfect knowledge of a given idea was thus fundamental to the medieval imagination and it was this faith that helped entrench the idea of Julius Caesar's Caesarean birth.

Before tracing the different stages of this entrenchment we must address one further preliminary question: Why were multiple etymologies so popular? Was not etymology a means to recover one ultimate signification? In exegesis, it was believed that God as the ultimate Word had created univocal significations at the beginning of time. For late antique and medieval exegetes, the current multiplicity of tongues and races represented a fall from grace. As Howard Bloch points out, "both history and grammar are bound by a common sense of loss and dispersion, by a common nostalgic longing for beginnings, and by a set of ontologically similar strategies of return." The conflict between linguistic determinism (the nostalgia for univocal meaning) and "the intellectual awareness of the socially determined nature of language" could not be resolved. ${ }^{6}$ Multiple etymologies find their place at the heart of this conflict: faith in the possibility of a return to the perfect one-ness collided with a passion for exhaustive research. ${ }^{7}$ For the etymology of "Caesarean section" legendary and medical material coalesced to form a complex web of ideas. 
One possible derivation of the term "Caesarean section" is from the phrase lex caesarea, which may have come from a renaming of the lex regia, or royal law, dating from approximately 715 B.c. This law, proclaimed under King Numa Pompilius, stated that it was unlalwful to bury a pregnant woman without attempting to cut out the child in order to save its life. ${ }^{8}$ Supposedly this law was rebaptized lex caesarea under the first Roman emperor, Caesar Augustus, Julius Caesar's adopted son. As intriguing as this suggestion is-establishing as it does a link between the law and Julius Caesar's family - neither the term itself nor its renaming is attested beyond doubt. ${ }^{9}$ The connection that was made between the two terms thus illustrates certain ways of (wishful) etymological thinking rather than any real historical development.

The most durable derivation of the name Caesar proved to be the one from caesus, "cut," first mentioned by Pliny the Elder (A.D. 23-79) in his Natural History: "Auspicatius enecta parente gignuntur, sicut Scipio Africanus prior natus, primusque Caesarum a caeso matris utero dictus, qua de causa et Caesones appellati. Simili modus natus est Manilium qui Carthaginem cum exercitu intravit" (It is a better omen when the mother dies in giving birth to the child; instances are the birth of the elder Scipio Africanus and of the first of the Caesars, who got that name from the surgical operation performed on his mother; the origin of the family named Caeso is also the same. Also Manilius who entered Carthage with his army was born in the same manner). ${ }^{10}$ This ambiguous passage caused many misunderstandings that had a direct influence on the development of the legend concerning Caesar's birth as well as on the extraordinary iconographic tradition that resulted from this legend. The persistent, but most productive, misreading of Pliny's text hinged on the question of the identity of this "first of the Caesars." Was he Scipio Africanus? The passage just cited could certainly be interpreted this way. Or does "primusque Caesarum" refer to another member of the gens Julia bearing the surname Caesar (as one entire branch of the family did)? But if so, which one? Pliny provided no clear-cut answer.

After Pliny, the surname Caesar continued to preoccupy various commentators for whom the problem of the manner of birth evoked by "Caesar" constituted but one problem among many. At the end of the third century, for example, Aelius Spartianus considered the etymological origin of "Caesar" in a letter to the emperor Diocletian. He grouped together four possibilities which-either together or separately-remained in vogue throughout the entire medieval period: (I) one of the 
Caesars, most likely the first to bear this surname, Sextus Julius Caesar, who was praetor in 208 B.C., killed an elephant (in Punic, caesar) during the second Punic war (2I8-2OI); ${ }^{11}$ (2) the first Caesar was cut from his mother's womb after her death (Aelius does not specify here which member of the family of the Caesars he has in mind); (3) one of the early Caesars was born with a big shock of hair (caesaries, from Sanskrit, Kéfah); or (4) he was born with bluish green eyes (Latin caesius, bluegreen). The first possibility is well attested through the existence of Roman coins showing Julius Caesar on one side and an elephant on the other, thus commemorating his ancestor's exploit. ${ }^{12}$

The grammarian Sextus Pompeius Festus, who flourished sometime in the first four centuries A.D., distinguished between those born by Caesarean, who are called caesones, and the possible reason for Caesar's gaining this surname, his abundant hair: "Caesones appellantur ex utero matris exsecti; Caesar, quod est cognomen Juliorum, a caesarie dictus est, quia scillicet cum caesarie natus est" (Caesones are called those who have been cut out of the mother's womb; Caesar, which is the surname of the Julians, comes from caesaries [a lot of hair] because he was born with much hair). Pompeius Festus's work reached the Middle Ages through an abridgment by Paul the Deacon (720?-799?) and thus played a role in the transmission of two of the etymological possibilities also envisaged by Aelius Spartianus: the abundant hair and the operation of cutting.

Isidore of Seville (ca. 570-636) in his Etymologies, characterized by Howard Bloch as a work where we find "the recuperation of all philosophy by grammar, and even ... a lexicology which takes on metaphysical proportions", made the definitive and unequivocal connection between Julius Caesar and Caesarean birth: "Caesar autem dictus, quod caeso mortuae matris utero prolatus eductusque fuerit, vel quia cum caesarie natus sit. A quo imperatores sequentes Caseares dicti, eo quod comati essent. Qui enim execto utero eximebantur, Caesones et Caesares appellabantur."13 Thus Isidore restricted himself to two possibilities for the origin of Caesar's surname: he was called Caesar because he was cut from his dead mother's womb or because he was born with abundant hair. Isidore then goes on to a general application of his explanation. The principal purpose of this passage was to explain why Roman rulers were called Caesars, but in the process Isidore succeeded in linking once and for all Caesarean birth to Julius Caesar. It was through this text, then, that the idea of Caesar's birth by Caesarean section was perpetuated and entered vernacular literature. 
Isidore's version of Caesar's birth was used at the beginning of a widely read compilation and translation of Roman historians, the anonymous Faits des Romains, written in French prose in the early thirteenth century: "Gaius Juilles Cesar fu tant eu vantre sa mere que il covint le ventre tranchier et ovrir ainz que il en poist oissir; et trova l'en que il avoit mout granz chevex. Por ce fu il apelez Cesar par sornon, car cist moz Cesar puet senefier ou chevelure ou trenchement" (Gaius Julius Caesar was so long in his mother's belly that one had to cut open the belly so that he could come out; and one found that he had a lot of hair. Therefore one gave him the surname Caesar, for this word Caesar can mean hair or cutting). ${ }^{14}$ Thus the Faits des Romains, by incorporating and translating Isidore's version of Caesar's birth, made it available to a very large vernacular audience.

The early years of Caesar's life as narrated in the Faits are based on Suetonius's (A.D. 69-140) The Twelve Caesars. But as the first sections of Suetonius's text were lost, the author of the Faits had to find another source: Isidore. The conquest of Gaul in the Faits, as well, is not recounted according to Suetonius but according to Caesar's De bellogallico. The Twelve Caesars was also known independently in thisperiod, not only as a source for the Faits; in fact, it was a staple of the medieval classroom. It is in this text that we find a passage that added to the confusion of medieval historiographers who had to deal with Caesar's life. In part 26 of his chapter on Caesar, Suetonius describes Caesar's conquest of Gaul. "During these nine years," we learn, "Caesar lost, one after the other, his mother, his daughter, and his grandson."15 Now, it was clear to most historiographers that a woman did not survive a Caesarean section. How, then, could one reconcile the version of Caesar's birth found in Isidore and the Faits with the late death of Caesar's mother mentioned in Suetonius (who relied on Caesar's own testimony in De bello gallico)? The solutions found to this problem by one medieval translator, most likely Jean du Chesne, merit close study, as they can be seen as paradigmatic for much of medieval historiography when we are presented with different versions of one event (based on conflicting yet authoritative sources) and are asked to choose the one most convincing to us. ${ }^{16}$ Jean du Chesne was commissioned by the Burgundian duke Charles the Bold to translate Caesar's De bello gallico, also known as the Commentaries. Jean was from Lille in Flanders and came to lead a very productive professional life at the court of Burgundy. For his translation of Caesar's text he used not only the Latin original and other texts, such as Geoffrey of Monmouth's 
Historia regum britanniae, but also his topographical knowledge of the regions where Caesar led his campaigns. He can thus be described as a learned clerk, and his relatively wide knowledge of Latin texts of this period explains some of the remarkable passages concerning Caesar's birth that we find in his translation. Since Caesar himself did not speak of his birth in the Commentaries, Jean found other sources for this event, one of them the Faits, as Flutre and Bossuat have shown. ${ }^{17}$

In one of the manuscripts of Jean's French translation of the Commentaries, two of the by now familiar possibilities for the origin of the surname Caesar are listed: the manner of birth and the abundant hair (both based on the Faits). ${ }^{18}$ The translator is inclined to believe Isidore, that Caesar was born by Caesarean section, rather than Suetonius. According to Jean, Suetonius blamed Isidore (obviously a chronological impossibility) for the false story of Caesar's birth and called it apocryphal (appocriffe, fol. 43v), since Caesar lost his mother by natural causes during the campaign in Gaul. The chronological confusion of these two authors is not unusual in the Middle Ages: since both Suetonius and Isidore were considered auctores who belonged to the established school curriculum, they were grouped together in "antiquity" without any concern for their real dates of birth. This is why Jean can assert blithely that Suetonius objected to Isidore's definitions of the term "Caesar." As for Caesar's abundant hair, Jean tells us that Suetonius insisted on Caesar's baldness, a condition that he apparently greatly disliked. In fact, Caesar's imperial ambitions were closely related to his baldness: as emperor he would no longer have to uncover his head and no one would notice his lack of hair. Maybe, Jean adds, he was called Caesar (meaning "having abundant hair") in jest, as one often calls people by a nickname designating the opposite of their real qualities or appearance. Or maybe the woman who died when Caesar was an adult was his mère de lait (wet nurse). In any case, Caesar had brought his baldness upon himself by walking around bareheaded during his youth and exposing his hair to rain and to heat. And so forth. This type of disconnected musing on the surname Caesar is a striking but by no means unusual example of the medieval translator's method. A digressive style of this sort reflects a certain insecurity in face of (textual) authority; rather than choosing between different versions, Jean lists all of them and even invents some more, thus displaying his erudition and at the same time avoiding the critical stance required in a later age of "critical editions."19

An ingenious version of Caesar's birth presenting the two most pop- 
ular etymological possibilities can be found in the early-fourteenthcentury Roman de Renart le Contrefait, another poem that relied heavily on the Faits for the parts dealing with Julius Caesar:
Avant que Julius fu nez,
Sa mere ouvrir l'enconvint;
Aultrement sur terre ne vint,
Car trop grant cheveulx il avoit,
Et pour ce naistre il ne pouvoit.
Et pour ce Cezar l'appellerent,
Que pour lui sa mere soierent.
Cezar, a droitte parleure,
Signifie chevelure;
Cezar si est detrenchement,
Qui bien parle proprement. 20

(Before Julius was born one had to open up his mother; otherwise he could not come to this earth [i.e., be born] for he had too much hair, and this is why he could not be born. For this reason he is called Caesar, because for him they cut open his mother. Caesar really means "hair"; Caesar means "cutting open", according to those who speak properly.)

This passage illustrates the popularity of the rhetorical figure known as ctymologia and the creative uses etymology could be put to. The paratactic listing of possibilities characteristic of antique and medieval commentators is complemented here by a narrative sequence connecting the two meanings of the word "Caesar." In the Roman de Renart le Contrefait, a monumental work of encyclopedic character, the adventures of Renart are often a mere pretext for theological and philosophical excurses. It is therefore fitting that this passage exhibits, en miniature as it were, techniques typical for the work as a whole. The treatment of etymology here, integrated as it is into a narrative framework, contrasts markedly with the above-cited involved passage on Caesar's birth offered by Jean du Chesne Iso years later. The contrasting aim and methods of a poet (the author of the Renart) and Jean as chronicler-translator can be illustrated through the juxtaposition of the two passages describing Caesar's birth: where one aims for narrative coherence, the other is content to list a whole series of etymological and legendary traditions without worrying about truth or logic. The author of the Roman de Renart le Contrefait also was a clerk, of course, but he used knowledge that formed part of the learned canon of the period and made it part of a narrative; or, as Emile Benveniste has shown in a different context, succession or sequence is transformed into 
causality. ${ }^{21}$ Both of these texts, then, are striking examples of what can best be described as creative etymology.

The works I have discussed so far all made reference to Isidore and his remarks on the etymology of the surname Caesar. In one of the later translations of Roman history, Jean Mansel's Histoires romaines, written in 1454, we again find the Faits version of Caesar's birth, this time, however, attributed to Lucan. ${ }^{22}$ Here is the text according to manuscript Arsenal 5088 (my transcription): "Pour ce que dorenanvant sera souvent parlé de Gayus Julius cesar et de ses fais qui furent haulz et merveilleux, Il couvient ensieuvir en ceste partie lucan qui plus a plain en traitte que nul autre" (Because we will now speak often of Julius Caesar and his deeds, which were noble and marvellous, we have to follow for this part Lucan, who deals more explicitly with this than anyone else [fol. 43v]). The sentence from the Faits (quoted above) describing Caesar's birth follows. Now, it is true, that Lucan was one of the sources for the Faits (although his text underwent an ideological transformation necessitated by the positive image of Caesar in the Faits). But Lucan most certainly did not mention Caesar's birth. It is clear, then, from Jean Mansel's text that the account of Caesar's birth in the Faits had attached itself so firmly to Caesar's name that no history of Caesar would be complete without it. ${ }^{23}$ There is no doubt that the Faits constituted the authoritative version of Caesar's life (and consequently of his birth) and that the responsibility of making abdominal delivery a truly "Caesarean" birth-and of creating the extraordinarily fertile iconographic tradition-lies with this text.

The strength and persistence of one of the etymological explanations of Caesar's name can be further illustrated through an Arabic manuscript of al-Bīrūnīs Chronology of Ancient Nations. In a fourteenth-century manuscript of this eleventh-century text we see a striking depiction of Caesar's birth. ${ }^{24}$ Four bearded men attend to a woman stretched out naked and presumably dead. One of the men carefully pulls out the baby through a large incision that spans the entire width of the woman's abdomen. The caption above the picture reads: “... and he is called Caesar because his mother died at the time of delivery and her belly was cut open and he was taken out."25 This statement, probably based on Isidore, does not make much sense in Arabic if the Latin word caesus (cut) is not supplied. However, this caption presupposes a familiarity with both Latin etymology and the story of Caesar's birth that is striking for the eleventh century. 
Two other versions of Caesar's birth (dating from the thirteenth century) deserve mention. One is in the Prosa bistorica of Alfonso the Wise, the other in a Catalan chronicle called Flos mundi. ${ }^{26}$ Alfonso's history offers five different explanations for the name Caesar: (I) the manner of his birth; (2) his abundant hair; (3) because he inaugurated the habit of cutting one's hair; (4) because in his early youth he killed an elephant; (5) because he killed so many enemies (cedere [to strike, to kill]). ${ }^{27}$ Reasons (3) and (5) have not so far appeared in our survey. They attest to a desire for the picturesque and for the pseudo-logical that we find in the Roman de Renart le Contrefait a century later. The last reason, for example, clearly built on the tradition of Caesar as a military leader and conqueror, as it could be found in the Faits and the almost contemporary Histoire ancienne jusqu'à César, texts certainly known to Alfonso. ${ }^{28}$

Other, even more farfetched reasons for Caesar's name can be found in the Flos mundi. The author constructs a whole story around Caesar's birth: one day in Rome, during some sort of skirmish, a woman was killed. A knight noticed that she was pregnant, cut her open, and saved the child. As this happened in the month of July, the child was given the name Julius, and because both his parents were killed that day he was called Caesar. This last explanation relies on the connections between cedere (to kill) and Caesar. According to Arturo Graf, who reports this curious episode in his book on the role of Rome in the medieval imagination, this is an example of the creativity of popular (as well as erudite) fantasy, which invented singular and marvelous origins for great men. ${ }^{29}$ The two passages just discussed also illustrate the principle of accretion to which most legends are subject. As the figure of Caesar took shape over the medieval period and captured the public's imagination, the legend acquired new and "plausible" elements, such as the dramatization of Caesar's valor reflected in the new connection of cedere and "Caesar."

The preoccupation with the possible connections between Julius Caesar and Caesarean section was not limited to areas in which a Romance language was spoken. The German term for Caesarean section, Kaiserschnitt (Kaiser, "emperor"; Schnitt, "incision"), grew out of similar speculations and fabulations, as did the term opération césarienne, coined by the Parisian surgeon François Rousset in I58I.

One interesting association of abdominal delivery with an emperor, or Kaiser, can be found in a German obstetrical text of the third quarter of the fifteenth century. ${ }^{30}$ It is a German version of Latin commentaries on the pseudo-Albertus Magnus's Secreta mulierum. In chapter eight (on 
birth) the author describes a Caesarean section and ends by saying: "und das man die frucht auss der muter leybe solle schneyden als der Erst kaiser hainrich genant kaiser hainrich [sic] der wart auss der muter leybe geschnitten" (and one should cut the fruit from the mother's body, as was cut from his mother's body the first emperor Heinrich, called the emperor Heinrich). One could assume from this statement that the text refers to the emperor Heinrich I, who was elected emperor in 919 and reigned till 936 . He is the only person that could possibly be designated as the first emperor Heinrich. A look at his life, though, reveals not one detail that could associate him with a birth by Caesarean section. ${ }^{31}$ The origin of this mysterious passage must lie elsewhere, most likely in the realm of the imagination. The new fantasy associating the emperor Heinrich with the operation reveals the close connection that must have existed in medieval authors' minds between surgical birth and the idea of "emperor." Heinrich was probably closer to the heart of the German commentator than Julius Caesar, and this is why Heinrich I gets the credit for the naming of the operation.

But the legend of Julius Caesar's birth was well known in Germany and provided a valid alternative explanation for the imperial association of the operation, as can be seen from a passage in Eucharius Roesslin's Der Swangern Frawen und Hebammen Rosegarten (I513) in which the author speaks of cases where the mother dies before delivery and the child may still be alive. The midwife is advised to make an incision in the mother's abdomen and to pull out the child. Immediately after this we read: "Also lesen wir in d'römer geschichten das der erst keiser Julius genant von seiner muoter leib geschnitten wart" (We read in the histories [or stories] of the Romans that the first emperor, called Julius, was cut from his mother's body). ${ }^{32}$ Thus Roesslin opts for the version that sees the originator of the term in Julius Caesar.

The passages from the pseudo-Albertus Magnus and Roesslin illustrate several popular misconceptions of the medieval period: that Julius Caesar was the first Roman emperor; that he was born by Caesarean section; and that the emperor Heinrich I was born in the same manner and gave the operation its name. Here is one more proof, then, for both the firm hold etymological thinking had on medieval minds and for the creativity this thinking could lead to.

How, then, did the term Caesarean section enter medical terminology? The traditions I have just traced explain the persistent association of 
Julius Caesar with this operation. Although some chroniclers expressed doubts about his birth, these were clearly not strong or convincing enough to destroy the legend of Caesar's birth. It is therefore not surprising that the earliest medical writers treating the operation perpetuated this idea. But whereas Bernard of Gordon, when speaking of abdominal delivery in his 1305 Lilium medicinae cites Pliny's vague reference to the "first of the Caesars," Guy de Chauliac in his 1363 Chirurgie boldly states "Thus Caesar was extracted, as one reads in the histories of the Romans." 33 Most likely, the "histories of the Romans" designate the Faits, and not Pliny, as some historians have believed. In I513, as we saw above, this passage was translated word for word into German by Eucharius Roesslin, who thus transported the idea of Julius Caesar's birth by Caesarean into German territory. None of these authors used the term Caesarean section, however.

It was François Rousset who was responsible for the permanent entrenchment of the term "Caesarean section" in medical terminology. In the dedication to the reader ("Au Lecteur") of his I58I treatise Traitté nouveau de l'bystérotomotokie, ou enfantement caesarien, Rousset states that he "baptized" the operation opération césarienne. Since Rousset wrote this treatise in French (a choice that was unusual and needed some justification) and at a time when the French language was receptive to neologisms, his term entered the French vocabulary immediately and permanently. Why did the term "Caesarean section" become permanently associated with Julius Caesar, although Rousset went back to Pliny's possible identification of the "first of the Caesars" as Scipio Africanus? Several facts may account for this: all through the Middle Ages Julius Caesar had been one of the most popular heroes; given the auspicious nature of a Caesarean birth as described by Pliny, it is not too surprising that such a hero should be singled out for a special fate by the wondrous nature of his birth. Another factor was the far-reaching and influential textual and iconographic tradition of the Faits des Romains, which left no doubt as to the details of Caesar's birth.

Thus Rousset's term seemed to sanction the long-standing popular and learned association of Julius Caesar with the Caesarean section, an association that led to much confusion concerning the true nature of Caesar's birth. ${ }^{34}$ Although ultimately misleading, "Caesarean section"more picturesque and evocative than most medical terms-proved to be a most enduring contribution to Western medical terminology. 
